Jurnal Iqra' Vol.3. No.1, Januari - Juni 2009

\title{
MERAJUT PERDAMAIAN MELALUI PENDIDIKAN ISLAM
}

\author{
Oleh: Sahari*
}

\begin{abstract}
Abstrak
Dalam konteks agama Islam, perdamaian merupakan salah satu cita-cita universal yang diusung melalui pengutusan Muhammad SAW sebagai pembawa risalah Islam. Misi penyempurnaan akhlaq manusia (liutammima makrima al-akhlaq) mengandaikan sebuah proses transformasi manusia menuju terciptanya manusia yang memiliki karakter positif.

Dalam hubungan antar elemen kebangsaan, dengan prinsip-prinsip penegakan akhlaq al-karimah ummat Islam Indonesia memiliki potensi besar untuk membangun hubungan harmonis di tengah situasi keberagaman kebudayaan. Untuk itulah, dibutuhkan upaya-upaya penggalian dan pembumian nilai-nilai perdamaian, anti-kekerasan dan keadilan guna mewujudkan kondisi masyarakat Indonesia yang lebih baik. Dengan jumlah yang mayoritas, ummat Islam seyogyanya dapat mengambil peran dan memberi sumbangsih besar terwujudnya keteraturan dalam kehidupan berbangsa dan bernegara, salahsatunnya melalui jalur pendidikan, baik formal, informal maupun non formal.
\end{abstract}

Kata Kunci: perdamaian, pendidikan Islam

\section{Pendahuluan}

Dewasa Belakangan ini masyarakat dunia dihantui perasaan khawatir karena banyak peristiwa dan aksi kekerasan yang muncul seperti anarkisme, perang, hingga terorisme global.

Di Indonesia, hal itu tampak sekali dalam berbagai kasus konflik dan anarkisme akibat perbedaan pandangan, pendapat, pikiran, ideologi, etnik dan bahkan agama yang selalu saja muncul di tengah-tengah kondisi bangsa yang hingga kini terus didera masalah dan krisis berkepanjangan di berbagai bidang kehidupan, termasuk krisis dalam dunia pendidikan, padahal keinginan untuk menikmati kedamaian adalah dambaan semua orang.

Karenanya banyak kalangan yang memperbincangkan persoalan ini. Selain peneliti dan ilmuwan, dokter, artis, mahasiswa, dan kalangan LSM banyak yang terlibat membicarakan bahaya perang dan kekerasan bagi kehidupan makhluk hidup di muka bumi. Di Indonesia, banyak seminar-seminar yang melibatkan banyak pakar yang berasal dari

\footnotetext{
* Penulis adalah dosen tetap pada Jurusan Tarbiyah Program Studi Pendidikan Agama Islam
} STAIN Manado. 
berbagai disiplin ilmu berbeda, mencari solusi untuk tercapainya kehidupan yang damai dan aman.

Bagi umat Islam kedamaian itu hanya dapat dicapai dengan jalan berpegang teguh kepada ajaran agama. Islam adalah sebuah agama yang lahir dan hadir untuk menciptakan kehidupan manusia yang penuh dengan kedamaian. Karena Islam sebagai sebuah kata bermakna damai. ${ }^{1}$ Perdamaian dalam Islam adalah nilai utama bagi para penganutnya dan harus diimplementasikan sebagai sikap dalam kehidupan. Dalam literatur-literatur keagamaan Islam baik al-Quran dan al-Hadist serta cerita-cerita tentang sejarah Islam, banyak sekali dokumen-dokumen yang mengandung spirit perdamaian dan keadilan baik berupa anjuran maupun perintah. Namun demikian tidak bisa dipungkiri banyak sekali permasalahan yang dihadapi oleh umat Islam dalam mewujudkan perdamaian tersebut. Dalam ajaran Islam juga di samping ada literatur yang menganjurkan perdamaian, juga ada beberapa dokumen dalam teks yang berbicara masalah perang. Hal inilah yang kemudian banyak dijadikan dasar dan landasan bagi individu atau kelompok dalam umat Islam untuk melakukan tindak kekerasan bahkan melakukan bom bunuh diri dengan mengatasnamakan jihad atau cara lain dengan menetapkan Islam sebagai standar syariat yang mengatur kehidupan publik secara umum yang harus dijalakan oleh semua agama di Indonesia.

\section{Nilai Perdamaian Dalam Kata Islam}

Di antara keistimewaan agama Islam adalah namanya. Berbeda dengan agama lain, nama agama ini bukan berasal dari nama pendirinya atau nama tempat penyebarannya. Tapi, nama Islam menunjukkan sikap dan sifat pemeluknya terhadap Allah.Yang memberi nama Islam juga bukan seseorang, bukan pula suatu masyarakat, tapi Allah Ta'ala, Pencipta alam semesta dan segala isinya. Jadi, Islam sudah dikenal sejak sebelum kedatangan Nabi Muhammad saw. dengan nama yang diberikan Allah.

Islam berasal dari kata 'salima yuslimu istislaam', dari akar kata ini juga terbentuk kata salm, silm dan seterusnya yang mengandung pengertian tunduk, kedamaian, kesejahteraan, keselamatan, penyerahan diri dan kepatuhan. ${ }^{2}$ Selain yaslamu salaam -yang berarti selamat, sejahtera, atau damai. Menurut bahasa Arab, pecahan kata Islam mengandung pengertian: Islamul wajh (ikhlas menyerahkan diri kepada Allah), istislama (tunduk secara total kepada Allah), salaamah atau saliim (suci dan bersih), salaam (selamat sejahtera), dan silm (tenang dan damai). Semua pengertian itu digunakan al-quran seperti di ayat-ayat berikut ini.

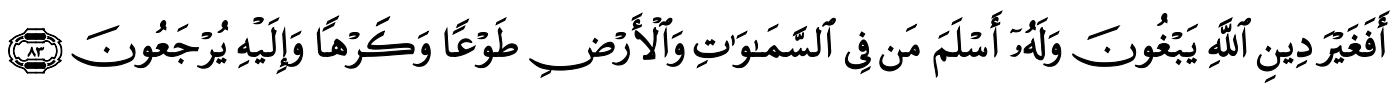

${ }^{1}$ Mukti Ali, Memahami Beberapa Aspek Ajaran Islam (Bandung: Mizan, 1991), h.50.

${ }^{2}$ Mohammad Daud Ali, Hukum Islam (Pengantar Ilmu Hukumdan Tata Hukum Islam di Indonesia) (Cet.V; Jakarta: Raja Grafindo Persada, 1996), h.19. 
Terjemahannya:

Maka apakah mereka mencari agama yang lain dari agama Allah, padahal kepadaNya-lah menyerahkan diri segala apa yang di langit dan di bumi, baik dengan suka maupun terpaksa dan Hanya kepada Allahlah mereka dikembalikan. (Ali Imran: 83) ${ }^{3}$

Terjemahannya:

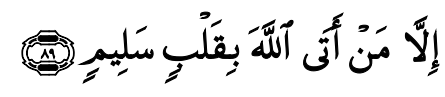

Kecuali orang-orang yang menghadap Allah dengan hati yang bersih. (AsySyu'araa':89). ${ }^{4}$

Sementara sebagai istilah, Islam memiliki arti: tunduk dan menerima segala perintah dan larangan Allah yang terdapat dalam wahyu yang diturunkan Allah kepada para Nabi dan Rasul yang terhimpun di dalam Alquran dan Sunnah. Manusia yang menerima ajaran Islam disebut muslim. Seorang muslim mengikuti ajaran Islam secara total dan perbuatannya membawa perdamaian dan keselamatan bagi manusia. Dia terikat untuk mengimani, menghayati, dan mengamalkan Alquran dan Sunnah.

Dari beberapa penjelasan di atas, maka sangat terang dan jelas bahwa Islam adalah agama damai. Namun persoalannya adalah apakah yang perlu dilakukan agar umat Islam mampu mengimplementasikan misi Islam damai? Kata "Islam" secara literal memang bermakna "damai", "selamat", "tenteram", dan "sentosa". 5

Konsep Islam sebagai agama damai inilah yang harus ditanamkan sedini mungkin kepada anak-anak kita, baik melalui pendidikan formal, informal maupun pendidikan non formal. Ada sebagian orang yang salah paham dalam mengartikan kata damai. Damai seringkali dimaknai adanya dua pihak yang hidup berdampingan secara harmonis. Padahal, kehidupan pribadi pun harus damai. Muslim yang batinnya tidak tenteram, nuraninya tidak konsisten, dan tidak istiqamah, berarti dirinya tidak damai. Islam mengajarkan hablum minallah (hubungan dengan Allah), hablum minannas (hubungan dengan sesama), dan hubungan dengan diri sendiri. Islam mengajarkan kita untuk hidup damai.

Konsep kedamaian yang dimaksud Islam bukan hanya antara dua pihak atau dengan orang lain, tapi juga untuk diri sendiri. Lebih spesifik, damai diartikan menjalin hubungan baik dengan pihak lain. Maksudnya, orang lain di luar diri kita, yang berbeda agama dengan kita. Perdamaian akan tercipta jika ada perjanjian atau konsensus untuk saling memahami, menghargai dan menghormati yang dibuat oleh kedua belah pihak, bahkan oleh multi pihak. Ini harus dijaga oleh kedua belah pihak, karena tidak mungkin perdamaian tercipta, jika keinginan untuk berdamai hanya datang dari salah satu pihak saja.

${ }^{3}$ Departemen Agama RI, Al-Qur'an dan Terjemahnya (Jakarta :PT. Karya Toha Putra Semarang, 1955), h. 89.

${ }^{4}$. Ibid., h. 580 .

${ }^{5}$ Masyfuk Zuhdi, Studi Islam ( Jilid. I; Jakarta: Raja Grafindo Persada, 1993), h. 3. 
Dengan demikian, langkah selanjutnya yang perlu dipikirkan kalangan pendidik adalah bagaimana membawa pendidikan perdamaian ke lingkungan sekolah dan kelas. Dilihat dari tantangan perdamaian di lingkungan sekolah, hal ini sangatlah relevan.

Sebagaimana diketahui, akhir-akhir ini sering kita saksikan melalui media, perkelahian antar pelajar dan perkelahian antar mahasiswa, baik yang berasal dari sekolah dan kampus yang sama maupun dari sekolah dan kampus yang berbeda terjadi setiap minggu di Jakarta dan cukup sering di kota-kota lain di Indonesia. Maka ada beberapa hal yang harus dipertimbangkan dan diperhatikan oleh pengelola pendidikan bila ingin mewujudkan perdamaian. yaitu:

\section{Masalah Kurikulum}

Dalam dunia pendidikan kita mengenal adamya kurukulum, kurikulum dapat dikatakan juga sebagai jantung atau urat nadi dalam suatu proses belajar mengajar yang berlangsung diberbagai lembaga pendidikan. Lalu bagaimana dengan kurikulum pendidikan agama Islam pada saat ini?.

Menjadikan manusia yang beriman dan bertakwa merupakan salah satu tujuan yang ingin dicapai oleh pendidikan Islam dengan keilmuan yang dimilikinya manusia diharapkan untuk lebih meningkatkan ketakwaannya kepada Allah SWT. Sebagai Tuhan yang maha mengetahui. ${ }^{6}$

Pada umumnya kurikulum yang digunakan lembaga-lembaga pendidikan Islam sama saja dengan kurikulum yang digunakan oleh lembaga pendidikan lain pada umumnya, namun yang membedakan adalah satuan pembelajarannya yang lebih diprioritaskan pada bidang agama Islam dibandingkan dengan pelajaran umum lainnya.

Sebelum membahas tentang problematika pada kurikulum PAI, kita harus mengetahui dahulu apa sebenarnya makna dari kurikulum itu sendiri. Kurikulum merupakan suatu rencana pendidikan, memberikan pedoman, dan pegangan tentang jenis, lingkup, urutan isi, serta proses pendidikan. Artinya kurikulum juga mencakup perencanaan metodologi pengajaran yang harus dilakukan. Aspek pelaksanaan kurikulum itu sendiri disebut sebagai proses pembelajaran.

Setiap sistem pendidikan pasti akan selalu dihadapkan dan berada diantara tekanantekanan konflik, seperti pengaruh tradisi dan tuntutan perubahan terhadap tatanan sosial kemasyarakatan. Dalam hal ini khususnya disebabkan kompleksitas system pendidikan. Dan setiap system pendidikan memiliki kemungkinan untuk "terlena" atau "terlepas" dari sikap objektivitasnya.

Dalam kurikulum pendidikan agama Islam yang kini diberlakukan dalam lembaga pendidikan agama Islam memiliki beberapa kendala yaitu seperti : profesionalisme guru PAI, media pembelajaran PAI, latar belakang peserta didik yang berbeda, serta alokasi

\footnotetext{
${ }^{6}$ Abd. Rahman Assegaf, Pendidikan Islam Integratif, Pusataka Pelajar Jogjakarta, 2004.
} 
waktu yang disediakan, namun dari beberapa kendala tersebut yang sangat dirasakan adalah tentang keprofesionalisme seorang guru PAI dalam penguasaan materi yang diajarkannya sehingga menimbulkan pemahaman yang baik bagi peserta didiknya. ${ }^{7}$

Mempertimbangkan semua per-masalahan ini, maka Kurikulum Pendidikan Agama Islam (PAI) kiranya perlu segera diperbaharui dan dikembangkan ke arah kurikulum berbasis kemajemukan. Untuk menciptakan perdamaian dan persaudaraan abadi antarpemeluk agama, perlu keberanian melakukan perubahan, terutama melalui kurikulum pendidikan berbasis keanekaragaman. Kurikulum seperti ini memungkinkan membongkar teologi agama masing-masing, yang selama ini cenderung eksklusif dan dogmatis.

Di samping itu, kurikulum tersebut memungkinkan untuk menampilkan ajaranajaran Islam yang toleran kepada peserta didik, sepanjang pendidikan yang dilaksanakan benar-benar didasarkan pada dasar agama ${ }^{8}$. Prinsip itu dinilai relevan, terutama untuk memasuki masa depan dunia yang ditandai dengan keanekaragaman budaya dan agama.

Sebuah teologi biasanya hanya mengklaim bahwa agamanya yang bias membangun kesejahteraan duniawi dan mengantar manusia dalam surgaTuhan. Pintu dan kamar surga itu pun hanya satu dan tidak bisa dibukaatau dimasuki, kecuali oleh pemeluk agamanya masing-masing.

Materi teologi yang diberikan di sekolah saat ini sangat mengkhawatirkan dan dapat mengganggu keharmonisan masyarakat agama dalam era pluralistic, apalagi kalau materi tersebut disampaikan dengan metode dogmatis yang ekstrim. Padahal, dalam era pluralistic seluruh masyarakat dari berbagai golongan dituntut saling tergantung demi perdamaian.

Di sinilah letak tantangan bagi agama, termasuk Islam, untuk kembali mendefinisikan dirinya di tengah-tengah agama lain. Tidak dapat disangkal, jika saat ini di masyarakat masih berkembang anggapan jika satu agama dengan lainnya adalah musuh yang harus dibuang jauh-jauh. Padahal, setiap ajaran agama, termasuk Islam, telah mengajarkan toleransi beragama.

Kita pun merasakan bahwa pendidikan agama yang diberikan di sekolah-sekolah kita pada umumnya tidak menghidupkan pendidikan perdamaian yang baik, bahkan cenderung berlawanan. Akibatnya, konflik sosial sering kali diperkeras oleh adanya legitimasi keagamaan yang diajarkan dalam pendidikan agama di sekolah-sekolah yang berada di daerah yang rawan konflik. Hal ini membuat konflik mempunyai akar dalam keyakinan keagamaan yang fundamental sehingga konflik sosial kekerasan semakin sulit diatasi, karena dipahami sebagai bagian dari panggilan agamanya.

Kenyataan menunjukkan bahwa pendidikan agama masih diajarkan dengan cara menafikan hak hidup agama yang lainnya (intoleran), seakan-akan hanya agamanya sendirilah yang benar dan mempunyai hak hidup, sementara agama yang lain salah, tersesat

\footnotetext{
${ }^{7}$ Imam Tholhah, Membuka Jendala Pendidikan (Cet. I; Jakarta: Grapindo Persada, 2004), h.230.

${ }^{8}$ Armai Arief, Pengantar Ilmu dan Metodologi Pendidikan Islam (Cet.I; Jakarta: Ciputat Press, 2002), h.33.
} 
dan terancam hak hidupnya, baik di kalangan mayoritas maupun yang minoritas. Semangat pendidikan keagamaan yang sempit ini, sudah barang tentu berlawanan secara fundamental dengan semangat pendidikan perdamaian, dan akan memperlemah persatuan bangsa.

Untuk memiliki toleransi beragama yang tinggi, mengembangkan sikap pluralisme pada peserta didik adalah mutlak segera "dilakukan" oleh seluruh pendidikan agama di Indonesia demi kedamaian sejati. Pendidikan agama Islam perlu segera menampilkan ajaran-ajaran Islam yang ramah dan toleran melalui kurikulum pendidikanya dengan tujuan dan menitikberatkan pada pemahaman dan upaya untuk bisa hidup dalam konteks perbedaan agama dan budaya, baik secara individual maupun secara kolompok dan tidak terjebak pada primordialisme dan ekslusifisme kelompok agama dan budaya yang sempit. ${ }^{9}$ Sehingga sikap-sikap pluralisme itu akan dapat ditumbuhkembangkan dalam diri generasi muda kita melalui dimensi-dimensi pendidikan agama dengan memperhatikan hal-hal seperti berikut:

a. Pendidikan agama seperti fiqih, tafsir tidak harus bersifat linier, namun menggunakan pendekatan muqaron. Ini menjadi sangat penting, karena anak tidak hanya dibekali pengetahuan atau pemahaman tentang ketentuan hukum dalam fiqih atau makna ayat yang tunggal, namun juga diberikan pandangan yang berbeda. Tentunya, bukan sekedar mengetahui yang berbeda, namun juga diberikan pengetahuan tentang mengapa bisa berbeda.

b. Untuk mengembangkan kecerdasan sosial, siswa juga harus diberikan pendidikan lintas agama. Hal ini dapat dilakukan dengan program dialog antar agama yang perlu diselenggarakan oleh lembaga pendidikan Islam . Sebagai contoh, dialog tentang "puasa" yang bisa menghadirkan para bikhsu atau agamawan dari agama lain. Program ini menjadi sangat strategis, khususnya untuk memberikan pemahaman kepada siswa bahwa ternyata puasa itu juga menjadi ajaran saudara-saudara kita yang beragama Budha. Dengan dialog seperti ini, peserta didik diharapkan akan mempunyai pemahaman khususnya dalam menilai keyakinan saudara-saudara kita yang berbeda agama. karena memang pada kenyataanya Di Luar Islampun Ada Keselamatan.

c. Untuk memahami realitas perbedaan dalam beragama, lembaga-lembaga pendidikan Islam bukan hanya sekedar menyelenggarakan dialog antar agama, namun juga menyelenggarakan program road show lintas agama. Program road show lintas agama ini adalah program nyata untuk menanamkan kepedulian dan solidaritas terhadap komunitas agama lain. Hal ini dengan cara mengirimkan siswa-siswa untuk ikut kerja bakti membersihkan gereja, wihara ataupun tempat suci lainnya. Kesadaran pluralitas bukan sekedar hanya memahami keberbedaan, namun juga harus ditunjukkan dengan sikap konkrit bahwa diantara kita sekalipun berbeda keyakinan, namun saudara dan saling membantu antar sesama.

9 Zuly Qodir, Memahami Keragaman di Indonesia Basis Pendidikan Inklusif (http://www.google.co.id/search?hl=id\&q=Zuly+Qodir), 21 Januari 2009. 
d. Untuk menanamkan kesadaran spiritual, pendidikan Islam perlu menyelenggarakan program seperti spiritual work camp, hal ini bisa dilakukan dengan cara mengirimkan siswa untuk ikut dalam sebuah keluarga selama beberapa hari, termasuk kemungkinan ikut pada keluarga yang berbeda agama. Siswa harus melebur dalam keluarga tersebut. Ia juga harus melakukan aktifitas sebagaimana aktifitas keseharian dari keluarga tersebut. Jika keluarga tersebut petani, maka ia harus pula membantu keluarga tersebut bertani dan sebagainya. Ini adalah suatu program yang sangat strategis untuk meningkatkan kepekaan serta solidaritas sosial. Pelajaran penting lainnya, adalah siswa dapat belajar bagaimana memahami kehidupan yang beragam. Dengan demikian, siswa akan mempunyai kesadaran dan kepekaan untuk menghargai dan menghormati orang lain.

e. Pada bulan Ramadhan, adalah bulan yang sangat strategis untuk menumbuhkan kepekaaan sosial pada anak didik. Dengan menyelenggarakan "program sahur on the road", misalnya. Karena dengan program ini, dapat dirancang sahur bersama antara siswa dengan anak-anak jalanan. Program ini juga memberikan manfaat langsung kepada siswa untuk menumbuhkan sikap kepekaan sosial, terutama pada orang-orang di sekitarnya yang kurang mampu. ${ }^{10}$

Selain beberapa hal di atas, perlu kiranya mengajarkan materi Aqidah Inklusif. Sebagaimana telah banyak diketahui umat Islam, aqidah berasal dari bahasa Arab yang berarti "kepercayaan", maksudnya ialah hal-hal yang diyakini oleh orang-orang beragama. Dalam Islam, aqidah selalu berhubungan dengan iman. Aqidah adalah ajaran sentral dalam Islam dan menjadi inti risalah Islam melalui Muhammad. Tegaknya aktivitas ke-Islaman dalam hidup dan kehidupan seseorang itulah yang dapat menerangkan bahwa orang itu memiliki akidah. Masalahnya karena iman itu bersegi teoritis dan ideal yang hanya dapat diketahui dengan bukti lahiriah dalam hidup dan kehidupan sehari-hari, terkadang menimbulkan "problem" tersendiri ketika harus berhadapan dengan "keimanan" dari orang yang beragama lain. Apalagi persoalan iman ini, juga merupakan inti bagi semua agama, jadi bukan hanya milik Islam saja. Maka, tak heran jika kemudian muncul persoalan mngklaim hanya keyakinannya yang benar sedangkan keyakinan orang lain diangap salah dan sesat, sehingga kemudian sering berakhir dengan konflik antar agama.

Program pencegahan kekerasan melalui pendidikan perlu mendapat perhatian serius bagi para pendidik di sekolah-sekolah, Terlebih di daerah-daerah yang pernah ditimpa konflik seperti Kalimantan Barat dan Tengah, Sulawesi Tengah, Maluku, Maluku Utara, Papua, dan Aceh. Selain di sekolah-sekolah negeri, sekolah-sekolah Islam seperti madrasah dan pesantren, dan organisasi Islam lain perlu dilibatkan juga dalam rangka meningkatkan cakupan pendidikan pencegahan kekerasan.

${ }^{10}$ Ibid. 


\section{Perilaku Para Pendidik}

Guru adalah komponen penting dalam pendidikan. Di pundaknya siswa menggantungkan harapan terhadap pelajaran yang diajarkannya. Benci atau sukanya siswa terhadap suatu pelajaran bergantung pada bagaimana guru mengajar. Saya katakan bahwa guru adalah ujung tombak dalam sistem pendidikan. Sebagai ujung tombak, tentu kita sangat berharap kepada peran guru dan kharismanya di hadapan siswa.

Semua pihak mengakui bahwa guru memiliki peran penting dalam membangun masa depan bangsa. Dikatakan demikian karena guru memiliki kapasitas mengajar dan mendidik. Sebuah kapasitas atau kecakapan khusus mencerdaskan dan menyiapkan masa depan anak lewat peran mereka. Jadi guru berperan besar di dalam dunia pendidikan. Jadi, guru, berada di garda terdepan dan unsur utama dalam mencerdaskan bangsa ini. Merujuk pada Undang-undang, Menurut UU No.2 tahun 2003 tentang Sistem Pendidikan Nasional, guru termasuk kelompok tenaga pendidikan, khususnya tenaga pendidik yang bertugas untuk membimbing, mengajar dan melatih peserta didik. Oleh sebab itu, tidak dapat dipungkiri bahwa keberadaan guru tidak dapat dilepaskan dalam keseluruhan kehidupan umat manusia, termasuk dalam membangun perdamaian di Indonesia. Dengan demikian, peran guru sebenarnya diperlukan dalam berbagai sudut kehidupan di sekolah dan di dalam masyarakat.

Agama Islam banyak mengatur, bagaimana seorang pendidik harus memperlakukan para siswanya, pendidikan agama berkaitan erat dengan pendidikan akhlak, tidak berlebihlebihan kalau kita katakan bahwa pendidikan akhlak dalam pengertian Islam adalah bagian yang tidak dapat dipisahkan dari pendidikan agama. Sebab yang dianggap baik oleh akhlak maka baik pula menurut agama, dan yang buruk adalah apa yang dianggap buruk oleh agama, sehingga nilai-nilai akhlak, keutamaan-keutamaan akhlak dalam masyarakat Islam adalah akhlak dan keutamaan yang diajarkan oleh agama. Sehingga seseorang muslim tidak sempurna agamanya sehingga menjadi baik. Sebab tujuan terakhir pendidikan Islam adalah mendidik jiwa dan akhlak.

Pendidik memegang peranan penting sekali dalam pendidikan akhlak untuk anakanak, oleh sebab itu hendaknya para guru mengajar mereka akhlak yang mulia sesuai yang diajarkan Islam seperti kebenaran, kejujuran, keikhlasan, kasih sayang, cinta kebaikan dan lain sebagainya.

Guru juga mengajarkan nilai dan faedahnya berpegang teguh kepada akhlak semenjak kecil. Sebab manusia itu sesuai dengan sifat asasinya menerima nasehat jika datangnya rasa cinta dan kasih sayang, sedang anak menolaknya jika disertai dengan kekerasan dan ancaman. Tepat sekali firman Allah dalam AlQur'an Surah Ali Imran ayat 159, yaitu :

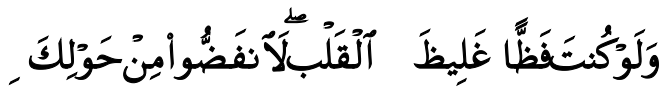


Terjemahannya :

"Jika engkau (Muhammad) kasar dan bengis tentu mereka meninggalkanmu“. ${ }^{11}$

Pendidikan akhlak yang diajarkan oleh AlQur'an bertumpu kepada aspek fitrah yang terdapat didalam diri manusia dan aspek wahyu (agama) kemudian kemauan dan tekad manusiawi.

Maka pendidikan akhlak yang perlu dilakukan oleh para pendidik terutama orang tua adalah dengan cara :

a. Menumbuhkembangkan dorongan dari dalam yang bersumber pada iman dan takwa, untuk ini perlu pendidikan agama

b. Meningkatkan pengetahuan tentang akhlak, lewat ilmu pengetahuan pengalaman dan latihan, agar dapat membedakan mana yang baik mana yang buruk.

c. Meningkatkan pendidikan kemauan, yang menumbuhkan pada manusia kebebasan memilih yang baik dan melaksanakannya selanjutnya kemauan itu akan mempengaruhi pikiran dan perasaan.

d. Latihan untuk melakukan yang baik serta mengajak orang lain untuk bersama-sama melakukan perbuatan baik tanpa terpaksa.

e. Pembiasaan dan pengulangan melaksanakan yang baik sehingga perbuatan baik itu menjadi keharusan moral dan perbuatan akhlak terpuji, kebiasaan yang mendalam tumbuh dan berkembang secara wajar dalam diri manusia. ${ }^{12}$

Oleh sebab itu, ketika kita kaitkan dengan peran guru dalam membangun perdamaian, kiranya banyak hal yang bisa dilakukan oleh guru. khususnya di daerah yang telah mengalami masa-masa konflik yang berkepanjangan. Partisipasi guru yang aktif dalam membangun damai sangat diharapkan.

Guru bisa memainkan peran strategis dalam meningkatkan kualitas SDM sebagaimana yang kita harapkan. Walau sebenarnya guru masih mengalami banyak keterbatasan dan dalam segala keterbatasan itu, para guru berusaha berbuat maksimal untuk tetap melaksanakan tugasnya sebagai pelaku pendidikan di garis terdepan. Dengan kreativitasnya yang masih terbatas, guru berusaha menyambung hidupnya. Guru juga mengingatkan berbagai pihak untuk membangun kesadaran dan kemauan politik yang sungguh-sungguh dalam menerapkan pendidikan dengan prioritas dalam membangun bangsa yang damai.

Dalam membangun perdamaian, guru sebenarnya bisa berpean besar. Guru bisa ikut terlibat mambangun damai. Banyak cara yang bisa dilakukan guru untuk membangun damai itu, Para guru tidak perlu berfikir terlalu berat, cukup dengan hal-hal yang sederhana. Misalnya, cukup berperan membangun visi perdamaian di sekolah. Guru dalam menjalankan aktivitas pembelajaran atau dalam berinteraksi dengan peserta didik,

${ }^{11}$ Departemen Agama RI, op. cit., h.103.

${ }^{12}$ Zakiah Daradjat, Pendidikan Islam dalam Keluarga dan Sekolah (Cet. II;Bandung ; Ruhama, 1995), h. 95. 
bisa mengajak dan menanamkan nilai-nilai yang mengarah kepada upaya membangun perdamaian. Guru bisa menggunakan pengalaman masa konflik sebagai pelajaran yang berarti. Paling tidak, dengan pengalaman tersebut, anak-anak akan bisa diajak untuk sadar akan arti dan nikmat perdamaian yang sedang kita nikmati.

Sebagai guru yang mentransfer dan menanamkan nilai-nilai edukatif, guru juga bisa mulai dari dalam diri guru sebagai teladan yang cinta damai. Misalnya dalam proses pembelajaran, sang guru bisa bersikap dan bertindak dalam perspektif damai. Sebagai contoh adalah dalam mengajar, guru tidak menggunakan pendekatan-pendekatan yang bernuansa kekerasan. Guru bisa menerapkan cara-cara yang demokratis dengan peserta didik, sekali gus juga bersikap demokratis sesama guru di sekolah. Dengan demikian, agenda pembelajaran yang sudah direncanakan bisa berjalan dengan damai, karena pada dasarnya guru siap untuk mensukseskan segala upaya perbaikan pendidikan. Tetapi harapan itu nampaknya masih jauh dari kenyataan, terbukti sampai hari ini masih sering terdengar guru yang memperlakukan anak didiknya dengan kasar, yang mengundang pertanyaan banyak orang, di mana batas tanggungjawab kita sebagai pendidik?"

Kerancuan akan makna tanggungjawab sebagai pendidik akan tetap melestarikan kultur kekerasan di dalam sekolah dan dalam masyarakat. Yang membatasi definisi tanggungjawab seorang pendidik bukanlah pagar sekolah. Batasan morallah yang menjadi definisi esensial bagi tanggungjawab mereka sebagai pendidik. Karena itu, entah di dalam pagar sekolah maupun di luar sekolah, para pendidik tetap memiliki tanggungjawab moral untuk mengatasi persoalan kekerasan dalam dunia pendidikan.

Ketika moralitas menjadi dasar yang mendefinisikan tanggungjawab sebagai seorang pendidik, maka dua jenis orientasi tanggungjawab menjadi bagian penting dari kinerjanya.

Pertama, pendidik mengidentifikasikan tanggungjawab melalui prinsip dasar tidak melakukan tindakan yang merusak (doing no harm). Prinsip tanggungjawab ini sifatnya ex post facto . Ini berarti bahwa pendidik bertanggungjawab atas tindakan yang telah dilakukan. Karena itu, ia mesti mengevaluasi terus menerus apakah keputusan dan tindakan yang telah dilakukannya memiliki dampak merusak, baik itu dari segi moral, mental dan fisik. ${ }^{13}$ Membiarkan kekerasan terjadi dalam lingkup sekolah sama saja menyetujui tindakan merusak.

Kedua, pendidik melangkah dari prinsip doing no harm menuju proactive responsibility. Ini berarti bahwa pendidik mesti menemukan niat-niat baik yang secara kelembagaan ingin direalisasikan demi berlangsungnya kinerja pendidikan, seperti, kualitas pembelajaran, relasi yang sehat antar individu sebagai warga negara, dll. Cakupan tanggungjawab yang demikian ini sifatnya antisipatif sebab terjadi sebelum tindakan itu sendiri (ex ante facto).

13 http://www.geocities.com/donikoesoema/batastanggungjawabpendidik.htm. 12 Januari 2009. 
Dua orientasi moral atas tanggung jawab pendidik ini menuntut mereka untuk senantiasa menyadari sumber-sumber yang melahirkan tanggungjawab mereka selama ini. Jika dipahami melalui batasan moral, maka tanggungjawab pendidik bukanlah sekedar tugas-tugas yang secara formal didefinisikan melalui job descriptions lembaga, melainkan merupakan tanggungjawab penuh dirinya sebagai individu yang sekaligus secara formal adalah pendidik. Di sini memisahkan batas tanggungjawab antara sekolah dan masyarakat merupakan pengingkaran tanggungjawab moral diri sebagai pendidik.

Para pendidik memiliki tanggung jawab secara moral untuk menciptakan sebuah iklim yang menghargai individu di manapun mereka berada. Jika kultur kekerasan ternyata ada di sekolah, sementara pihak sekolah membiarkan semua itu terjadi terus menerus, tanggungjawab moral mereka sebagai pendidik dipertanyakan. Jika kita sering berteriak lantang tentang krisis moral para pemimpin kita, apakah kita sebagai pemimpin pendidikan juga telah merefleksikan cakupan tanggung jawab moral kita dalam kasus maraknya perilaku kekerasan dalam lembaga pendidikan?

Para pendidik mestinya memahami bahwa tanggungjawab itu bukan sekedar jenis tanggungjawab terhadap (responsibility to), yang secara sempit didefinisikan secara formal melalui struktur kelembagaan, seperti, tanggungjawab terhadap siswa, orang tua para staf guru, melainkan juga tanggungjawab untuk (responsibility for), yaitu tanggungjawab untuk menciptakan sebuah lingkungan belajar yang aman, nyaman dan teduh bagi berlangsungnya proses pembelajaran.

Lebih dari itu, para pendidik sesungguhnya memiliki tanggung jawab sebagai (responsibility as), yaitu, sebuah esensi tanggungjawab berdasarkan keluasan identitas dirinya. Pendidik bertanggungjawab sebagai sesama manusia, karena itu apa saja yang berkaitan dengan promosi kebaikan, keadilan, kehidupan dan penghargaan martabat manusia merupakan bagian dasar dari tanggungjawabnya.

Selain itu, pendidik bertanggungjawab sebagai administrator sekolah, yang menjaga agar visi kelembagaan tetap pada garis cita-citanya. Pendidik juga bertanggungjawab sebagai warganegara yang kebetulan menjadi pendidik, kepala sekolah, pengawas, dll. Tanggungjawabnya sebagai warga negara inilah yang membuat dirinya sebagai pendidik tidak dapat memisahkan cakupan kinerjanya sekedar dalam batasan formal-struktural tanggungjawabnya, apalagi batasan fisik tanggungjawab berdasarkan batas pagar sekolah. ${ }^{14}$

Perilaku kekerasan itu dapat terkikis jika pendidik menyadari tanggungjawab moralnya. Batas tanggungjawab pendidik adalah nilai-nilai moral, yaitu, menghindari tindakan dan kebijakan yang merusak dan mengejar nilai-nilai kebaikan. Jika nilai-nilai moral itu bukan menjadi batas yang mendefinisikan tanggungjawab kita sebagai pendidik, kekerasan itu akan tetap terjadi dalam lembaga pendidikan kita. 


\section{Pengelolaan Sekolah}

Dalam rangka mencegah kekerasan melalui pendidikan, salah satu pendekatan yang dapat digunakan adalah menciptakan iklim ruang kelas yang positif. Lingkungan belajar di kelas diciptakan sehingga memungkinkan siswa menyelesaikan masalah, bekerja dan belajar bersama siswa lain, dan melaksanakan tugas-tugas bersama secara kolaboratif. Proses belajar yang menekankan kerjasama dan interdependensi positif, bukan hanya kompetisi, perlu dipraktikkan di ruang kelas.

Dalam hal ini, gagasan tentang manajemen konflik berbasis sekolah (school-based conflict management) yang telah penulis sampaikan di harian ini beberapa waktu lalu, perlu dipertimbangkan.

Selain itu, pelarangan terhadap hukuman fisik di sekolah perlu dilakukan. Cara-cara fisik dalam menanamkan disiplin di kalangan peserta didik akan memberikan role-model resolusi konflik yang buruk, merendahkan harga diri siswa, dan mempersulit anak-anak mempercayai orang dewasa.

Mengelola dan menjalankan sekolah dengan cara-cara yang demokratis perlu digalakkan. Lokakarya dan pelatihan perlu dilakukan di bidang ini kepada guru dan pegawai sekolah serta siswa. Secara khusus lagi, mendidik guru supaya memahami hak-hak anak perlu dilakukan lebih luas lagi.

Menciptakan lingkungan sekolah yang aman dari tindakan kekerasan (termasuk yang menyangkut narkoba dan minuman keras, serta lain-lain). Pekan perdamaian dan perayaan perdamaian di sekolah perlu diperkenalkan dan dilakukan secara rutin. Demikian juga kegiatan-kegiatan yang menopang hal ini seperti lomba menulis (esai ilmiah dan cerpen) di bidang rekonsiliasi, dan perayaan bersama untuk anak-anak yang berasal dari berbagai daerah dan latar belakang.

Perdamaian akan tercipta jika terbangun kepercayaan antarkomponen masyarakat. Menumbuhkan sikap saling mempercayai ini memerlukan waktu yang relatif lama dan dibutuhkan kebulatan tekad serta konsistensi antara kata dengan perbuatan. Kedua belah pihak harus mengikis kecurigaan masing-masing sambil menunjukkan bukti pada pihak lain bahwa mereka ingin kedamaian.

Penulis merasa yakin Islam bisa menampilkan diri sebagai agama rahmatan lil'alamin apabila para ulama, para pendidik dan tokoh-tokoh agama dapat menampilkan ajaran agama dan sikap yang damai. Memang banyak orang yang mempertanyakan kenapa agama Islam yang sangat konsen memperjuangkan ajaran perdamaian justru tidak identik dengan keselamatan, keadilan, serta ketenteraman, tapi malah selalu identik dengan kekerasan? Hal ini mungkin disebabkan oleh perilaku kelompok minoritas Islam yang tidak memahami ajaran Islam secara komprehensif. Mereka menggunakan agama untuk melegitimasi tindak kekerasan yang mereka lakukan. Dampaknya, Islam tercoreng oleh perbuatan mereka. Untuk itu, mari kita sadarkan orang di sekitar kita yang melakukan kekerasan atas nama agama Islam. Karena wajah Islam tergantung perbuatan umatnya. 


\section{Kesimpulan}

Memang tidak mudah mengajarkan pendidikan perdamaian kepada anak-anak. mengatakan memberi pemahaman damai, tujuan hidup damai, sekaligus mempertahankan pedamaian itu di tingkat lokal, nasional, dan global memang harus dilakukan secara pelanpelan dan berkesinambungan. Sebab selain budaya damai, di sisi yang sebalah ternyata ada budaya kekerasan. Di sinilah kita harus memberi penjelasan kepada anak-anak bagaimana cara menekan kekerasan itu agar tidak terjadi lagi. Anak-anak pun harus mendapat penjelasan bahwa dengan menerapkan pendidikan perdamaian itu maka mereka akan segera memperoleh kedamaian itu di lingkungan bermain, di sekolah, maupun di rumah.

Pendidikan perdamaian itu bisa memanfaatkan pelajaran agama yang diberikan di sekolah-sekolah dengan memasukkan pentingnya perdamaian itu. Sayangnya selama ini pelajaran agama diberikan di sekolah sebatas mengajarkan ritual agama serta dogma-dogma agama itu sendiri. Sebenarnya pendidikan perdamaian bisa disampaikan di sana. Oleh karena itu, kita berharap lewat pelajaran agama yang di dalamnya mengakui adanya pluralitas maka pendidikan perdamaian itu bisa dengan mudah disampaikan. Dengan cara itu, dialog di antara anak-anak itu akan terjadi dengan melihat berbagai agama yang berbicara tentang perdamaian.

Selain dari materi (konten) pelajaran, salah satu item penting yang juga turut menentukan tercapainya tujuan pendidikan adalah cara yang digunakan oleh pendidik ketika menyampaikannya, untuk mewujudkan perdamaian sangat dibutuhkan metode pembelajaran yang betul-betul arif dan bijaksana, guru agama yang biasanya menyampaikan ajaran agama dengan cara-cara ekstrim apalagi yang berhubungan dengan doktrin-doktrin ke-agamaan harus dirubah, Untuk memberikan pemahaman keagamaan kepada anak didik, tidak harus dengan cara ekstrim, pengajaran teologis memang sangat perlu, tetapi tidak harus menanamkan sikap permusuhan kepada kelompok masyarakat yang tidak sepaham , seagama, dengan kita.

\section{Daftar Pustaka}

Al-Abrasyi, Muhammad Atiyah, fi Falsafat al-Tarbiyah al-Islamiyyah. Beirut: Dar al-Fikr. 1996.

Ali, Mukti, Memahami Beberapa Aspek Ajaran Islam, Bandung: Mizan, 1991.

Assegaf, Abd. Rahman, Pendidikan Islam Integratif, Pusataka Pelajar Jogjakarta, 2004

Departemen Agama RI, Al-Qur'an dan Terjemahnya, Semarang : yayasan Penyelenggara Penterjemah Al-Qur'an, 1983 
Departemen Pendidikan dan Kebudayaan 4, Kamus Besar Bahasa Indonesia, Edisi , I, Cet. I ; Jakarta : Balai Pustaka, 1991.

Daud Ali, Mohammad, Hukum Islam (Pengantar Ilmu Hukumdan Tata Hukum Islam di Indonesia), Cet.V; Jakarta: Raja Grafindo Persada, 1996.

http://www.geocities.com/donikoesoema/batastanggungjawabpendidik.htm. 12 Januari $\underline{2009}$.

Zuhdi, Masyfuk, Studi Islam, Jilid. I; Jakarta: Raja Grafindo Persada, 1993

Zuly Qodir, Memahami Keragaman di Indonesia Basis Pendidikan Inklusif (http://www.google.co.id/search?hl=id\&q=Zuly+Qodir), 21 Januari 2009.

Zakiah Daradjat, Pendidikan Islam dalam Keluarga dan Sekolah ( Cet. II;(Bandung ; Ruhama, 1995. 